\title{
The effect of occupational choice on job satisfaction and occupational accidents in the construction sector: A case study on Rize and Çorum in Turkey
}

\author{
İlker Ustabaş ${ }^{*}$ (D), Hatice Sarı1 ${ }^{10}$, Seda Fandaklı ${ }^{\text {(D) }}$ \\ ${ }^{1}$ Recep Tayyip Erdoğan University, Department of Civil Engineering, Rize, Turkey \\ ${ }^{2}$ Avrasya University, Department of Occupational Health and Safety, Trabzon, Turkey
}

\begin{abstract}
The construction sector is a sector that employs a significant amount of employees in Turkey and appeals to many branches of work and professions. In Turkey, the construction sector ranks first in the statistics of occupational accidents, with the highest fatality every year. In this study, how the construction workers choose their profession in Turkey, whether they have professional qualification certificates, the relationship between career choice and job satisfaction, and the perceptions of workers in the construction sector about occupational accidents were determined through questionnaires. The questionnaires were applied to 72 construction workers working at four different construction sites. The prepared questionnaires are determined how the construction workers' choice of occupation affected their job satisfaction using a fivepoint Likert scale (strongly disagree, disagree, undecided, agree, strongly agree). The average and standard deviation of the answers given by the construction workers to the questionnaires were found. The relationship between job choice and job satisfaction, between job satisfaction and occupational accident, was determined by correlation analysis. As a result of the study, it has been determined that other people choose a significant portion of the construction workers in Turkey. The job satisfaction of the construction workers who desire a profession is higher. Most of the construction workers working in Turkey perceive work accidents as death or severe injury that will require hospital treatment.
\end{abstract}

\section{Keywords}

Job satisfaction; Career choice; Occupational accident; Construction worker

Received: 25 July 2021; Accepted: 18 November 2021

ISSN: 2630-5771 (online) ( 2021 Golden Light Publishing All rights reserved.

\section{Introduction}

Occupational accidents and occupational diseases in working life vary considerably according to occupational groups and countries. Turkey is among the developing countries classified as developed countries, developing countries, and underdeveloped countries. Turkey, which is among the developing countries, has more occupational accidents than developed countries. It is seen that the safety culture in workplaces in Turkey has not sufficiently been settled. In Turkey, the construction sector is an important sector that provides employment. When the construction sector employees in Turkey are examined, it is seen that they have a profile that reflects all segments of the society, from contractors to engineers, from technicians to foremen, from apprentices to

* Corresponding author

Email: ilker.ustabas@erdogan.edu.tr 
construction workers. When factors such as education levels, economic conditions, living conditions, and understanding and perception levels of the employees in the construction sector in Turkey are examined, it shows a significant variation among the employees. There are also important differences in the behaviours of the employees in the Turkish construction sector in terms of dangerous situations and behaviours, which William Henrich put forward and stated as the cause of the accidents. In Turkey, the construction sector is a sector that ranks first in the fatal occupational accident statistics every year [14]. The high number of occupational accidents in Turkey's construction sector leads to much research in this field $[3,5]$. The specific conditions of the construction industry play an essential role in the occurrence of occupational accidents in the construction sector. These conditions are the work of many workers, physical difficulties, the fact that the results are generally short-term and involve continuous movement in an unsystematic way. The fact that it is a sector that includes works performed by different organizations and subcontractors, the existence of unskilled labour that is constantly moving, the working conditions vary according to the workplace. It is possible to list the factors such as the change in the workplace, the dispersed and wide working area, the height of the working environment, the natural climatic conditions, the low level of education of the employees [6-12].

In developed countries, it is considered to be a profession for career development. There are many studies on careers according to occupations and the reasons for having these careers [13]. It is stated as having preliminary knowledge about this profession at the stage of acquiring a job and making a decision by developing and maturing this prior knowledge in the following process. Employees develop career knowledge through consultation and training. Career selection and career development include stages ranging from receiving consultancy support from relevant experts [13]. In choosing a profession to include these processes, the individual has sufficient equipment for the work in which he will continue his life in the future and can make a decision at the level of enough knowledge and desire in line with his desires and wishes. When the workers in the construction sector in Turkey are examined, it is stated in the studies that some of them are under the age of 15 , while the other significant part starts their profession between the ages of 15 and 20 [14]. In this process, mostly family elders and their social environment cause construction workers to start working life. After starting the construction industry, while working as a flat construction worker, the careers of these children and young workers are shaped and progressed by the decision of the journeymen and foremen.

Even though the construction sector in Turkey is exceptionally open to technological developments, workers do heavy work and live in environments where hygiene problems are common. These mentioned factors cause issues such as occupational dependency or job satisfaction of construction workers. In a work environment perceived as an obligation under a heavy workload, job dissatisfaction affects the employees psychologically as professional dissatisfaction. Thus, it appears to affect work accidents and occupational diseases in the construction sector in Turkey.

In this study, it will be determined how the construction workers in Turkey choose their profession. When the construction workers start their work, the reasons for selecting the domain will be determined. It will be investigated how the angel selection preferences of construction workers in Turkey affect their job satisfaction. The effect of career choice, job satisfaction, and work accidents will be determined. The perception of work accidents of construction workers in Turkey will be revealed.

\subsection{Vocational selection stages and decision- making process}

Many literature studies state that many factors play a role in the career choice stages and decisionmaking processes of individuals [13,15]. It is thought that career choice is affected by many factors. Choosing the right career is essential to 
enable individuals to lead rewarding lives, stay motivated at work, and achieve remarkable productivity, thus laying the groundwork for organizational success and sustainability [15]. In addition to acquiring a profession, an employee also determines their life in the coming years while choosing this profession. Figure 1 shows the career selection and decision-making phases introduced by Lent et al. [16]. Fig. 1 shows that personal characteristics and dependent variables are a selection process according to the person's consciousness, skills, and business life expectations.

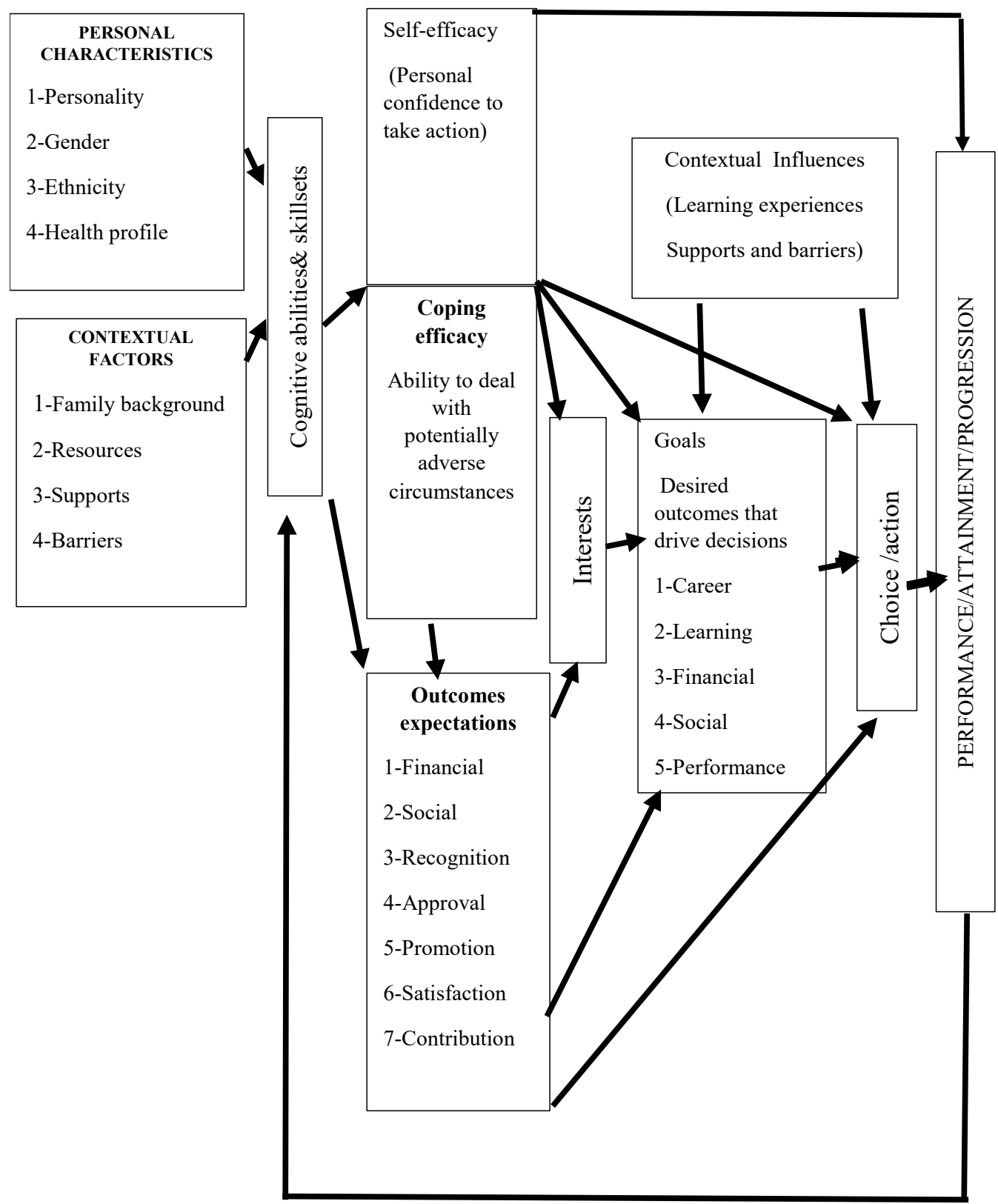

Fig. 1. The career choice and advancement model developed by Crawforda et al. [13] and Lent et al. [16] 
As indicated in Fig. 1, the individual decides on the choice of profession. The individual, who determines his professional career himself, is supported by occupational health and safety approaches throughout his working life and continues his professional life working with the methods revealed with a scientific approach to ensure whole mental well-being. In this model, a business life based on financial, individual and social reward systems is mentioned to provide the morale and motivation of the employees during their professional life [17]. With these awards, employees are motivated to work. The mental wellbeing of an employee who chooses his job as an individual and is supported to work with a reward system throughout his working life is reduced, thereby reducing the probability of having a work accident.

\subsection{Profession and professional commitment}

Occupation constitutes an essential part of the life of employees. The occupational preferences of employees in Turkey include a critical part of their lives, such as their circle of friends, place of residence, and social needs. Occupation is defined as working in a job for a certain period to earn a living so that individuals can survive [18, 19]. When we look at the definition of the profession, we come across financial gain for the replacement of life. Even though the construction workers in Turkey do their professional life to earn a living and make a living for themselves and their families, most of the workers stay in construction sites in different cities because their place of work is far from where they live. In this way, the work environment of the employee is also the living space. This is a factor that negatively affects the social worker. It causes problems between job and job satisfaction and creates spiritual deficiencies in the construction site workers. In occupational health and safety, it is aimed to ensure the physical and mental well-being of employees. The development of occupational addiction in a professional is another factor that will positively affect their behaviour in the workplace. Greenhaus first expressed the professional commitment as 'individuals giving importance to a job or a career. Based on the definition of Greenhaus in the Job Engagement Model, which is accepted as the primary reference source in the related field, Morrow names the concept as career commitment and associates it with other types of commitment $[18,20-22]$. In other words, professional dedication and career commitment show the importance of the employee's work.

\section{Methodology}

In this study, questionnaires prepared at four different construction sites in Rize and Çorum, from which legal permissions were obtained, were applied in June and July of 2021. The companies where the surveys were conducted are the construction sites of the companies engaged in airline construction, highway construction, medical school building construction and factory construction in the organized industry. The companies to which the survey was applied are large-scale companies in their field in Turkey. The questionnaires were applied to 18 people from each company selected from different units chosen using the random selection method by asking preprepared questionnaires under the supervision of the interviewer. The survey participants were told that a survey would be administered in advance, and the prepared survey questions were asked to the employees in a face-to-face interview in a suitable office under the supervision of the interviewer. A total of 72 construction workers who participated in the survey answered the survey questions within an average of one hour, and the interviewer filled in the survey papers. Questionnaire questions were prepared according to the publications of researchers working on a similar subject and the research team's knowledge, experience, and opinions. The literature review was the most decisive factor in the preparation of the survey questions. The questionnaires were organized in three stages. The surveys asked at what age the employees started their profession, whether they had vocational qualification certificates, and how they chose their work. In the second stage of the survey, questions were asked about the job 
satisfaction of the employees. In the third part of the questionnaire, questions were asked about whether the employees had a work accident and perceived the work accident. The questionnaire was prepared in the form of qualitative data collection with nominal data with yes or no answers and a fivepoint Likert scale as I strongly agree (1), agree (2), undecided (3), disagree (4) and strongly disagree (5). A questionnaire was created according to the Likert scale specified for the questions in Tables 1 and 2 .

\section{Results}

The answers to the questions applied to 72 construction workers from four different construction sites were evaluated with graphics and tables.

Fig. 2 shows the number of construction workers who participated in the survey according to their working hours in the profession. In Figure 1, it is seen that the number of those who declared that they have worked as construction workers in less than a year is 15 , and the ratio of this number to all workers participating in the survey is $20.8 \%$. This shows that the rate of new workers working at the construction site is $1 / 5$ compared to the old workers, and the employment of new workers at the construction sites in this study is at a high value.

In Fig. 3, the rate of those who started their profession at 18 is $12.5 \%$ out of 72 employees who participated in the survey. $5.6 \%$ of the construction workers who participated in the survey stated that they started working younger than 16 years. According to the regulation on the employment of child and young workers, people who have not completed the age of 18 should not be employed at the construction sites [23]. According to the workers' statements in this study, they start working at construction sites at a young age.

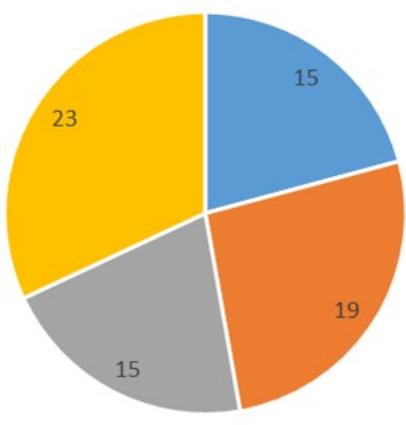

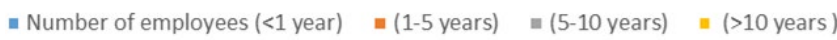

Fig. 2. Number of construction workers surveyed according to their working time in the profession

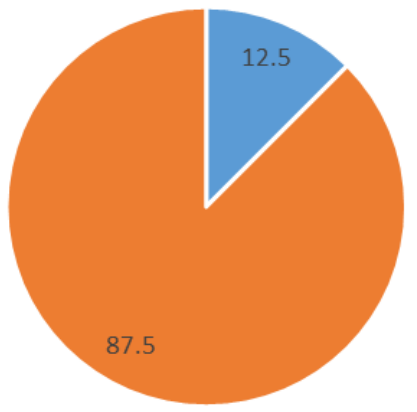

" $<18$ ages ratio $(\%) \quad$ - $\geq 18$ ages ratio $(\%)$

Fig. 3. The ratio of the number of employees whose starting age is less than 18 
Fig. 4 shows the proportion of construction workers who do not have a professional qualification certificate, which was asked to 72 construction workers who participated in the survey. It is seen that the rate of employees working at the construction site without a professional qualification certificate is $63.9 \%$.

Fig. 5 shows the ratio of whether the employee chooses to work as a construction worker or not. $43.1 \%$ of the employees who participated in the survey stated that they did not make their career choices themselves. They reported that their choice of profession was determined by their friends $(51.5 \%)$, their parents $(39.4 \%)$, their second-degree relatives $(0.9 \%)$, their social environment $(0.6 \%)$, and other factors $(7.6 \%)$. This situation shows that the workers working in construction do not choose the profession of their own accord.
Fig. 6 shows the proportions of the answers given by the construction workers to the question "I enjoy my job". $5.6 \%$ of the construction workers who participated in the survey stated that they were unsatisfied with their job, and $15.3 \%$ were not satisfied. In Fig. 5, it is seen that the rate of those who are satisfied and satisfied is $54.1 \%$. The average of the scores they gave between 1 and 5 for the question "I enjoy my job" was found to be 3.43, and the sample standard deviation was $\mathrm{S}=1.136$. Table 1 shows the average, standard deviation and frequencies of the answers given by the construction workers to the questions prepared according to the factors affecting job satisfaction.

Table 1 shows "I would like to have a job with weekend and annual leave." which has the highest mean (4.389) and the lowest standard deviation $(\mathrm{S}=0.779)$.

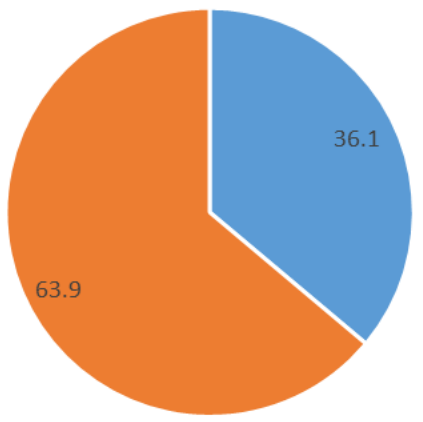

- with qualification certificate ratio (\%) = without qualification certificate ratio (\%)

Fig. 4. The ratio of employees with/without vocational qualification certificate

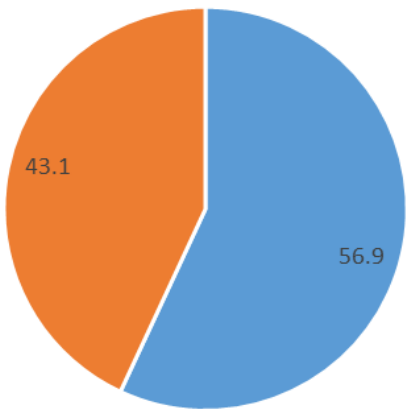

- Choose their professionratio (\%) = Do not choose their profession ratio (\%)

Fig. 5. The ratio of the employee's own / someone else's choice of profession 

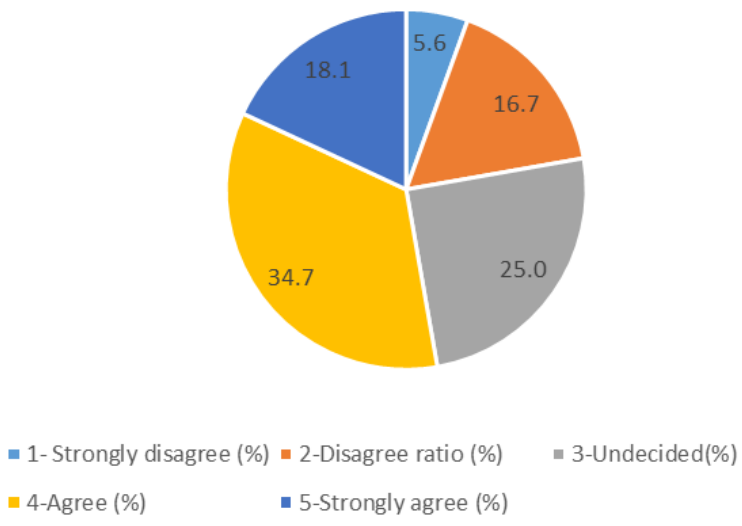

Fig. 6. Rates of construction workers enjoying their job

Table 1. Mean, standard deviation and frequencies of the answers to the questions on job satisfaction

\begin{tabular}{|c|c|c|c|c|c|c|c|}
\hline \multirow{2}{*}{ Questions } & \multirow{2}{*}{ Mean } & \multirow{2}{*}{$\begin{array}{l}\text { Standard } \\
\text { deviation }\end{array}$} & \multicolumn{5}{|c|}{ Frequencies } \\
\hline & & & 1 & 2 & 3 & 4 & 5 \\
\hline $\begin{array}{l}\text { If I were to get the same pay, I would choose } \\
\text { another job. }\end{array}$ & 3.764 & 1.216 & 6 & 5 & 12 & 26 & 23 \\
\hline $\begin{array}{l}\text { I have to work in construction because I can't } \\
\text { find a job }\end{array}$ & 3.861 & 1.130 & 4 & 6 & 9 & 30 & 23 \\
\hline $\begin{array}{l}\text { I don't need to love my job, and it's enough } \\
\text { for me to support my family. }\end{array}$ & 3.833 & 1.300 & 8 & 5 & 4 & 29 & 26 \\
\hline $\begin{array}{l}\text { I would like to work in a cleaner and more } \\
\text { respectable job. }\end{array}$ & 4.208 & 0.978 & 2 & 4 & 4 & 29 & 33 \\
\hline $\begin{array}{l}\text { Working in construction is not a choice but a } \\
\text { necessity for me. }\end{array}$ & 3.861 & 1.237 & 4 & 10 & 6 & 24 & 28 \\
\hline $\begin{array}{l}\text { I endure working conditions in order not to } \\
\text { be unemployed. }\end{array}$ & 3.847 & 1.195 & 4 & 8 & 9 & 25 & 26 \\
\hline $\begin{array}{l}\text { I would not recommend anyone to work in } \\
\text { construction jobs unless it is necessary. }\end{array}$ & 4.056 & 1.221 & 4 & 7 & 6 & 19 & 36 \\
\hline $\begin{array}{l}\text { I would like to have a job with weekend and } \\
\text { annual leave. }\end{array}$ & 4.389 & 0.779 & 2 & 0 & 1 & 34 & 35 \\
\hline $\begin{array}{l}\text { I would like another job where I can work } \\
\text { without having to go abroad }\end{array}$ & 4.306 & 0.988 & 2 & 4 & 3 & 24 & 39 \\
\hline $\begin{array}{l}\text { I'm scared while working in construction, but } \\
\text { I have to work. }\end{array}$ & 3.583 & 1.264 & 6 & 11 & 9 & 27 & 19 \\
\hline
\end{tabular}

For this reason, it can be said that the employees participating in the survey prefer working at construction sites to working at weekends. The question "I would like to work in another job without having to go abroad" got the secondhighest average score $(4,306)$. The third highest average score $(4,056)$ was given to the question "I do not recommend anyone to work in construction works unless it is necessary".
In Table 2, it is seen that the average of the answers given by the construction workers to the question "I had a work accident" is 2.390 , and the standard deviation is 2.389 . $65.2 \%$ of the 72 workers who participated in the survey declared that they had not had a work accident, and $34.8 \%$ of them had a work accident. The highest score of 4,097 in Table 2 belongs to "People who have a work accident should be hospitalized." 
Table 2. Mean, standard deviation and frequencies of the answers to the questions on occupational accidents detection

\begin{tabular}{|c|c|c|c|c|c|c|c|}
\hline \multirow{2}{*}{ Questions } & \multirow{2}{*}{ Mean } & \multirow{2}{*}{$\begin{array}{l}\text { Standard } \\
\text { deviation }\end{array}$} & \multicolumn{5}{|c|}{ Frequencies } \\
\hline & & & 1 & 2 & 3 & 4 & 5 \\
\hline I had an occupational accident. & 2.389 & 1.170 & 16 & 31 & 9 & 11 & 5 \\
\hline $\begin{array}{l}\text { If I had an accident at work, I would have } \\
\text { died. }\end{array}$ & 3.444 & 1.393 & 8 & 13 & 14 & 16 & 21 \\
\hline $\begin{array}{l}\text { It means that the person who fell from the } \\
\text { elevator shaft and died had an accident. }\end{array}$ & 3.944 & 1.149 & 5 & 6 & 2 & 37 & 22 \\
\hline $\begin{array}{l}\text { Those who have an occupational accident } \\
\text { should be hospitalized. }\end{array}$ & 4.097 & 0.790 & 0 & 4 & 8 & 39 & 21 \\
\hline $\begin{array}{l}\text { I don't need to go to the hospital if I have a } \\
\text { nail on my foot. }\end{array}$ & 2.528 & 1.256 & 20 & 16 & 20 & 10 & 6 \\
\hline $\begin{array}{l}\text { If I hit my hand with a hammer and injured } \\
\text { it, it's my fault. }\end{array}$ & 3.653 & 0.966 & 3 & 7 & 12 & 40 & 10 \\
\hline $\begin{array}{l}\text { I don't need to go to the hospital without } \\
\text { falling off the scaffolding. }\end{array}$ & 2.903 & 1.406 & 16 & 15 & 14 & 16 & 11 \\
\hline $\begin{array}{l}\text { If I have an accident at work, I go to the } \\
\text { hospital. }\end{array}$ & 3.931 & 1.105 & 5 & 4 & 5 & 35 & 23 \\
\hline $\begin{array}{l}\text { I cut my hand almost daily on the } \\
\text { construction site, but I don't go to the } \\
\text { hospital. This is not an occupational } \\
\text { accident. }\end{array}$ & 3.042 & 1.316 & 13 & 12 & 16 & 22 & 9 \\
\hline $\begin{array}{l}\text { Why is it an occupational accident to fight } \\
\text { and get injured at the construction site? }\end{array}$ & 3.583 & 1.242 & 5 & 13 & 8 & 30 & 16 \\
\hline $\begin{array}{l}\text { If my arm is broken, the employer will allow } \\
\text { it. }\end{array}$ & 3.556 & 1.232 & 9 & 5 & 9 & 35 & 14 \\
\hline $\begin{array}{l}\text { If I trip and fall, I will tape it and continue } \\
\text { working if my hand is cut off. }\end{array}$ & 3.250 & 1.297 & 10 & 10 & 18 & 21 & 13 \\
\hline $\begin{array}{l}\text { Every day, either our hands or feet are } \\
\text { slightly injured, but we either continue to } \\
\text { work or rest at the construction site. }\end{array}$ & 3.583 & 1.058 & 4 & 11 & 5 & 43 & 9 \\
\hline $\begin{array}{l}\text { I had an occupational accident before and } \\
\text { was treated at the hospital. }\end{array}$ & 2.264 & 1.175 & 17 & 37 & 5 & 6 & 7 \\
\hline $\begin{array}{l}\text { If I tripped and fell on the construction site, I } \\
\text { would go to the hospital and say it was an } \\
\text { occupational accident if my arm were } \\
\text { swollen. }\end{array}$ & 2.931 & 1.191 & 4 & 32 & 8 & 19 & 9 \\
\hline
\end{tabular}

It is seen that the average score is given to the statement "If I have a work accident, I will go to the hospital." is 3,931. It is seen that the average score is given to the statement "I don't need to go to the hospital if I have a nail in my foot." is 2.528 . Another view with the lowest score $(2,264)$ in Table 2 is "I had a work accident before and was treated at the hospital." It is seen that the score given to this statement and the score given by the employees to the idea in Table 1 are compatible with each other.

Table 3 shows the correlation coefficients that determine the relationship between construction workers making their own career choices, liking their job and having a work accident. The correlation coefficient between -1 and 1 indicates a negative association of -1 and a positive relationship. 
Table 3. The relationship among employee's choice of job, job satisfaction and occupational accidents

\begin{tabular}{lc}
\hline Question & $\begin{array}{c}\text { Coefficient of } \\
\text { correlation }\end{array}$ \\
\hline $\begin{array}{l}\text { Did you choose to work in this } \\
\text { profession by yourself? }\end{array}$ & $-0,406$ \\
I love my job. & \\
\hline $\begin{array}{l}\text { Did you choose to work in this } \\
\text { profession yourself? }\end{array}$ & 0,1142 \\
I had an accident. & 0,1796 \\
\hline I love my job. & \\
I had an accident. & \\
\hline
\end{tabular}

In Table 1, those who prefer to work in the profession by themselves gave a score of 1 , and those who do their job-loving gave a 5. The employees who choose their jobs are happier in their careers. No significant relationship was found between the employee who loves his job and having a work accident.

\section{Discussion}

In this study, the number of newly employed workers at the construction sites surveyed was $20.8 \%$. The construction sector in Turkey is an important sector in which new employees are engaged. The share of the construction sector in total employment was $6.93 \%$ in $2018,5.52 \%$ in 2019 and $6.12 \%$ in 2020, according to TUIK 2020 economic activity branches and distribution of those employed by years [24]. It is seen that the construction sites in this study continue to use new employees. It is stated that the new employees' starting to work in the workplaces is a factor that increases occupational accidents. It is observed that the frequency of occupational accidents is higher in newly recruited employees due to inexperience and in former employees due to overconfidence [25].

According to the regulation on the employment of child and young workers, people who have not completed the age of 18 should not be employed at the construction sites [23]. According to the workers' statements in this study, they start working at the construction sites at a younger age.
Employees are required to obtain a professional qualification certificate. With the issued communiqués, 40 more professions were added in $09 / 04 / 2021$ to the 183 professions needed to have a professional qualification certificate, and a professional qualification certificate was made compulsory in 223 jobs [26]. With the 6th Communiqué in 2021, the obligation to have professional certifications in 40 occupations, made mandatory, will come into effect on 09/04/2022 [26]. In most professions operating in the construction business, employees will be subject to criminal proceedings if they have a professional qualification certificate and employers employ workers who do not have a professional qualification certificate. As seen that $63.9 \%$ of the construction workers, as seen in Figure 3, did not have a professional qualification certificate at the date of 2021 when this study was conducted. This situation indicates that the speed of obtaining professional qualification certificates of the employees is slow. For the construction workers to get the professional competence certificate, public institutions, organizations, and employers should encourage the employees.

In Fig. 5, 19.4\% of the construction workers are delighted with their work, and $34 \%$ say they are satisfied. It is seen that the rate of delighted employees of the surveyed construction workers is 54.1\%. Pavitra Dhamija et al. [27] found satisfaction rates between $60 \%$ and $67.5 \%$ by age group in a study in the finance sector, where they measured job satisfaction according to different variables. This study calculated the mean and standard deviation of job satisfaction as 3.43 and 1.136, respectively. Bakan et al. [28] found the mean to be 3.7385 and standard deviation to be $\mathrm{S}=0.67701$ in 130 employees in the study of academicians working at universities to measure job satisfaction between 1 and 5. It is seen that the fulfillment of the construction workers in this study has lower scores when compared to the studies conducted by Pavitra et al. [27] and Bakan et al. [28] with finance workers and academics.

In Table 2, it is understood that the rate of $34.8 \%$ is high compared to the occupational accident 
perception survey. Another critical factor is the perception of occupational accidents by the workers working at the construction site. Considering the definition of a work accident, it is the unexpected loss of the employee or workplace at the workplace or during the execution of the work. Workers working at the construction site understand the concept of having an occupational accident as either dying or being damaged at a level that requires hospital care. A worker's nail stabbing at a construction site is not perceived as a work accident, and construction workers do not even think of going to the hospital for treatment. They consider hitting their hand with a hammer or stepping on a nail while working as their fault. According to the construction workers' perception of having a work accident, it is understood that the workers in Turkey have a large number of accidents every working day. The worker whose net is not injured and who does not go to a hospital for treatment does not see his work accident even as an accident.

It is seen that the situation faced by the workers working in the construction sector in Turkey during their choice of profession and continuing their job is quite different from the working life specified for developed countries. It is seen that some of the construction workers in Turkey determine the profession they will do until the age of 18 , as well as their family, social and economic environment [14]. Working time and wages in the same workplace are among the essential issues that employees complain about. If it is desired to reduce occupational accidents in the construction sector in Turkey, the development of the structure of obtaining a profession and the respect and love of the employee for their work should be among the issues to be considered. Construction workers in Turkey generally put their emphasis on their profession behind in the priority list, as they choose this job, it develops against their will, they only look at it with the feeling of gaining financial gain for their family in remote construction site conditions in the family environment, and they usually finish their career development when they reach the master stage. These are the most critical factors affecting the fact that it ranks first in occupational accidents in the construction sector.

To protect employees from work accidents in the workplace, hazards are identified with a proactive approach and measures are taken against the risks employees may encounter. With the risk assessment, it is tried to protect the employees from work accidents and occupational diseases by taking measures according to physical, chemical, biological and ergonomic risks, from the building, workplace and its annexes, to situations such as the placement of workplace machinery and equipment, ambient temperature, workplace hygiene. Psychosocial risk factors affect the performance of employees in the workplace environment and play an essential role in protecting them from work accidents. Individuals working in a healthy work environment believe that their work demands are not excessive. They do not need to sacrifice their family's life or other meaningful non-work roles to perform well at work [29]. They reflect the positive emotions and energies of the employees arising from the family to their business life. This situation affects the employee's psychological state in the working environment and increases work performance. A profession that the construction workers in Turkey do not choose with their own will and decisions will not make them feel psychosocial and spiritual well-being in the future, which may lead to alienation from the profession and low moral motivation.

Occupational alienation and lack of motivation in terms of morale are factors that negatively affect job security [5]. Employees who choose their jobs have higher job satisfaction. No significant relationship was found between job satisfaction and occupational accident. In their study, Jha and Bhattacharyya [33] stated that there is a positive relationship between job choice and job satisfaction $(\beta=0.247, p=0.005)$. This situation is stated by Tzafrir [30], and it is also noted in the work of Hunter and Schmidt [31] and Katou and Budhwar [32]. The fact that the employee has determined the job that is suitable for him in terms of his wishes, expectations and career development increases job satisfaction in the future. In this study, it was 
observed that the job satisfaction of the construction workers who made their own choice of occupation was higher (correlation coefficient was -0.406), the correlation coefficient was 0.1142 in the analysis between the occupational accident of the employee who chose his work himself, the correlation coefficient of the correlation analysis of job satisfaction was 0.1794 . In other words, there was no significant difference in the statement that the employee had a work accident because the employee made the choice of profession himself or felt satisfied at work. It is thought that the factors of perception of the work accident of the employees affect this determination. Perceive accidents as work accidents.

\section{Conclusion}

As a result of this study, the following points were determined.

1. It was determined that the career choices of a significant part of the construction workers participating in this study were made by people other than themselves.

2. Some of the workers working in construction started their working life in the building at an age that does not comply with the law.

3. Although the construction workers must have a professional certificate, a significant part of the workers in this study work without a professional qualification certificate.

4. The construction site workers participating in this study consider death or severe injuries as work accidents.

5. The job satisfaction of the construction workers who made their own choice of profession is higher.

6. According to the occupational accident perceptions of the workers at the construction site, there is no significant relationship between job satisfaction and occupational accident.

\section{Ethics Committee Permission}

The authors acquired ethics committee permission for surveys implemented in this paper from the Science and Engineering Fields Human Subjects
Ethics Committee of Recep Tayyip Erdoğan University (Date: 02/06/2021; No:2021/01).

\section{Declaration of conflicting interests}

The author(s) declared no potential conflicts of interest with respect to the research, authorship, and/or publication of this article.

\section{References}

[1] Penkey P, Siddiqui NA (2015) A review on accident pyramid and its empirical interpretation in oil \& gas industry (Upstream) Siva. International Journal of Scientific and Research Publications 5(1).

[2] Ministry of Labor and Social Security Publication. Occupational Health and Safety Law Guidebook No. 6331, 2015, Ankara.

[3] Cavus A. (2016) Classifying and examining the causes of occupational accident in the construction sector in turkey. Journal of Engineering and Science, 4(2): 13-24.

[4] Ustabas I (2016) Measuring the level of perception of the civil engineers working in rize province and obtaining their opinions on safety practice. Journal of Economic Management Research 07: 111-126. (doi: 10.17373/uheyad.2016715179).

[5] Kaynak R, Toklu AT, Elci M, Toklu IT (2016) Effects of occupational health and safety practices on organizational commitment, work alienation, and job performance: using the pls-sem approach. International Journal of Business and Management, Canadian Center of Science and Education, (doi:10.5539/ijbm.v11n5p146).

[6] Çetinkaya U. Investigation of Construction Occupational Accidents and Costs in the Aegean Region. Master's Thesis, Aegean University, 2012.

[7] Ural S, Ocal ME, Atılgan H, Kaya A. Risk assessment in terms of occupational safety in construction works. Occupational Health and Safety Symposium, October 2012, Ankara, Turkey.

[8] Ocal ME. Occupational accidents in the construction sector. Occupational Health and Safety Symposium in Construction Sector, December 2006, Adana, Turkey.

[9] Gorucu MN, Mungen U. State Occupational health and safety supervision in construction branch and evaluation of the project for the prevention of falls from height in construction. 3rd Occupational Health and Safety Symposium, October 2011, Çanakkale, Turkey. 
[10] Kamder G. Evaluation of Occupational Accidents in the Construction Sector of Trabzon Province. Master's Thesis, Karadeniz Technical University, 2014.

[11] Mhando YB (2021) Factors of inefficient use of personal protective equipment: A survey of construction workers at Arusha urban in Tanzania, Journal of Construction Engineering, Management and Innovation 4(1): 1-11 (doi: 10.31462/jcemi. 2021.01001011).

[12] Çelik GT, Aydınlı S, Bazaati S (2021) Safety net applications in developing countries: Turkey and Iran case study, Journal of Construction Engineering, Management and Innovation, 4(1): 12-21 (doi: 10.31462/jcemi.2021.01012021).

[13] Crawforda L, Beverley LW, French, E (2015) Career choice and the experience of project-based work. Procedia- Social and Behavioral Sciences 194: 55-64.

[14] Celik T Occupational accident and occupational disease in the construction sector in TurkeyGiresun Sample. Master's Thesis, Ordu University, 2019.

[15] Nyamwange J (2016), Influence of student's interest on career choice among first-year university students in public and private universities in Kisii county, Kenya. Journal of Education and Practice 7(4).

[16] Lent R, Brown SD, Hackett G (1994). Toward a unifying social cognitive theory of career and academic interest, choice, and performance. Journal of Vocational Behavior 45: 79-122.

[17] Azeez M, Gambatese J, Hernandez S (2019) What do construction workers really want? a study about representation, importance, and perception of us construction. Journal of Civil Engineering and Management 145(7), (doi:10.1061/(ASCE)CO. 1943-7862.0001669).

[18] Tak B, Ciftcioglu BA (2008) An empirical study to examine professional commitment and employee's intention to stay in the organization. Ankara University The journal of SBF 63(4).

[19] Lee K, Carswell JJ, Allen NJ (2000) A metaanalytic review of occupational commitment: relation with person and work-related variables. Journal of Applied Psychology 85: 799-811.

[20] Greenhaus JH (1971) an investigation of the role of career salience in vocational behavior. Journal of Vocational Behavior 1: 209-216.

[21] Morrow PC (1983) Concept redundancy in organizational research: the case of work commitment. The Academy of Management Review 8(3): 486-500.

[22] Morrow PC. The Theory and Measurement of Work Commitment. JAI Press, Greenwich, 1993.

[23] Regulation on Procedures and Principles of Employing Child and Young Worker, Official Journal Date: 06.04.2004 Official Journal Issue: 25425.

[24] Gultekin Karakas D, Yusufi F, Hisarciklilar M (2021) Evaluation of turkish construction industry working standards based on sectoral development. Journal of Mulkiye 45(1): 191-230.

[25] Camkurt MZ (2013) The effect of personal characteristics of employees on occurrence of work accidents. TUHIS Business Law and Economy Journal 24(6).

[26] Vocational Qualification Institute Authority Communiqué on Professions Requiring Professional Qualification Certificate, 9 Nisan 2021, Official Journal, Issue:31449.

[27] Dhamija P, Gupta S, Bag S (2019) Measuring of job satisfaction: the use of quality of work life factors. Benchmarking: An International Journal 26(3): 871-892.

[28] Bakan I, Buyukbese T, Ersahan B, Sezer B (2014) Effects of job satisfaction on job performance and occupational commitment. International Journal of Management and Information Technology 9(1): 1472-1480.

[29] Kossek EE, Kalliath T, Kalliath P (2012). Achieving employee well-being in a changing work environment an expert commentary on current scholarship. International Journal of Manpower 33(7):738-753.

[30] Tzafrir SS (2006). A universalistic perspective for explaining the relationship between HRM practices and firm performance at different points in time. Journal of Managerial Psychology 21(2): 109-130.

[31] Hunter EJ, Schmidt LF (1982) Ability tests: economic benefits versus the issue of fairness. Industrial Relations 21(3): 293-309.

[32] Katou AA, Budwar PS (2007) The effects of human resource management policies on organizational performance in greek manufacturing firms. Thunderbird International Business Review 49(1): 1-35.

[33] Jha S, Bhattacharyya SS (2012) Study of perceived recruitment practices and their relationships to job satisfaction. Synergy 10(1). 